\title{
МОГУЋИ РАЗЛОЗИ ЗА НАСТАНАК ПЕРИОСТАЛНЕ РЕАКЦИЈЕ НА РЕБРИМА ДЕЧЈИХ ИНДИВИДУА У АРХЕОЛОШКОМ КОНТЕКСТУ
}

\author{
Драгана Вуловић \\ Археолошки институт, Београд \\ Наташа Миладиновић-Радмиловић \\ Археолошки институт, Београд
}

\begin{tabular}{r|c} 
e-mail: dragana.vulovic@gmail.com & Оригинални научни рад \\
Примљено: 27. 4. 2021. & УДК: 904:616.392”652”(497.11) \\
Прихваћено: 9. 6. 2021. & $\begin{array}{l}904: 572.781 .08-053.2(497.11) \\
902.2(497.11)\end{array}$
\end{tabular}

\begin{abstract}
Апстракт: Периостална реакиија у виду поротичних лезија или новоформиране кости није тако чест налаз на ребрима дечјих индивидуа из археолошког контекста. Лезије се јављају како на спољашьој, тако и на унутрашьој површини ребара, а поред саме локаичје лезија и морфолошког изгледа, разлика је присутна и у диференцијалној дијагнози. Најчешћи узрок настанка ове врсте лезија су метаболичка обољења (попут скорбута) и болести доњег респираторног тракта и плућна обољења (нпр. туберкулоза). Скорбут је метаболичко обољење које настаје услед недостатка витамина Це и карактеришу га специфичне промене на костима кранијалног и посткранијалног скелета. Код плућних обољења (запаљење плућа, бронхитис, канщер, плућна туберкулоза) могу се појавити специфичне промене на унутрашњој страни ребара, које указују да се болест доњег респираторног тракта, проширила директно кроз плеуру и на повриину ребра. Туберкулоза је специфично инфективно обољење, које узрокује бактерија из Mycobacterium tuberculosis комплекса, а у последњим фазама болести прате га и карактеристичне промене на скелету, између осталог и промене на унутрашьој страни ребара. У тексту ћемо приказати изглед, етиологију ових лезија, као и диференцијалне дијагнозе. Лезије смо посматрали на скелетима дечјих индивидуа откривених на два касноантичка локалитета у Србији: Naissus, локалитет Jагодин мала - Булевар војводе Мишића, и на локалитету Бегов мост - Станичење.
\end{abstract}

Кључне речи: периостеална реакција, ребра, скорбут, туберкулоза, Јагодин мала, Бегов мост

\section{Увод}

Покосница (periosteum) везивна је опна која прекрива спољашњу површину кости, осим када су у питању зглобне површине и сезамоидне кости. Причвршћена је за кост колагеним влакнима, која потичу из спољног 
слоја покоснице, и која продиру у кортекс у правцу одређеном силама затезања мишића (Bisseret et al. 2015, 323). Читав спектар бенигних, малигних и системских стања и обољења, у било ком старосном добу, могу да стимулишу формирање нове кости на покосници, а сам процес се назива периостална реакција (Bisseret et al. 2015, 322). Сама локација лезија, као и њихов морфолошки изглед, користе се у клиничкој пракси приликом дијагностике. Периостална реакција и новоформирана кост су чест клинички налаз у читавом спектру патолошких стања као што су трауме, инфекције, крварења, метаболичка обољења, тумори, венски проблеми, поремећаји у развоју, ендокрини поремећаји, али су присутне и код нормалног развоја кости (Assis and Keenleyside 2019; Davies-Barrett et al. 2019; De Silva et al. 2003; Edeiken et al. 1966; Lewis 2018, 131; Morrone et al. 2021; Ortner 2003, 88; Rana et al. 2009; Shopfner 1966; Waldron 2009, 116; Weston 2008, 2012, итд.).

Иако су ребра, поготово дечјих индивидуа, из археолошког контекста најчешће уништена и фрагментована, услед различитих тафономских процеса у земљи или пак приликом ископавања и депоновања остеолошког материјала, она пружају обиље информација о здрављу испитиваних индивидуа. Ребра чине део грудног коша и на тај начин штите виталне унутрашње органе. Са спољашње стране преко њих прелази сплет мишића и крвних судова. Патолошке промене на ребрима дечјих индивидуа јављају се и на њиховим спољашњим и на унутрашњим површинама. Поред саме локације, ове промене се разликују у морфолошком изгледу и јављају се као последица различитих обољења. Најчешћи узрок настанка ове врсте лезија јесу метаболичка обољења (попут скорбута) и болести доњег респираторног тракта и плућна обољења (попут туберкулозе).

\section{Скорбут}

Скорбут је метаболичко обољење које настаје у било ком старосном добу услед дефицита витамина Це (аскорбинска киселина), неопходног за стварање колагена, остеоида и цементне супстанце која повезује ендотелне ћелије крвних судова. Колаген чини базу свих везивних ткива коже, крвних судова, хрскавице и костију, штити и регулише биолошке процесе других ензима. За разлику од осталих сисара, човек и други примати не могу да синтетишу овај витамин у организму, те је потребно његово свакодневно уношење кроз исхрану. Витамин Це је доступан у широком спектру намирница. Највише га има у свежем воћу (посебно у цитрусном) и поврћу, у мањем проценту се налази у млеку, месу и риби, док га у житарицама нема нимало (Aufderheide and Rodríguez-Martín 1998, 310; Brickley et al. 2020, 
43). Иако његова тачна улога у синтези колагена није најјаснија, проблеми у самој синтези стварају низ последица као што су крварење, отежано зарастање рана (појаву петехија и пурпура), итд. ${ }^{1}$ Крварење може бити или спонтано или након мањих повреда крвних судова, што свакако указује на проблем у структури ових судова. Бол и слабост у удовима, код особа које имају скорбут, вероватно су повезане са мањом количином витамина Це, неопходног за синтезу карнитина, без којег не може да се производи енергија у мишићима. Овај витамин тесно је повезан и са формирањем крвних компоненти и са метаболизмом гвожђа и фолата. Особе са дефицитом витамина Це вероватно ће развити анемију. Крварење које се јавља као последица скорбута, такође, може довести до анемије. С обзиром на то да асистира у неутрализовању и уништавању патогена, али и производњи различитих заштитних антиоксиданаса, витамин Це има и важну улогу у одржавању имуног система. Многобројне студије су показале да су особе које имају мањак овог витамина склоније инфекцијама (Bourbou 2014, 86; Brickley et al. $2020,52)$. Скорбут може бити повезан и са специфичним, културолошким понашањима, као што је нпр. процес одвикавања од дојења и преласка на чврсту храну богату житарицама. Деца која пате од дефицита овог витамина подложнија су инфекцијама, и то инфекцији средњег уха (otitis media), пнеумонији, дифтерији, пробавним сметњама, итд. (Jaffe 1972). Болест се различито манифестује код деце и одраслих; у оба облика, међутим, јављају се повремене хеморагије (крварења) у кожи, слузокожи, деснима, мишићима и костима, што може да узрокује анемију (Ђурић-Срејић 1995, 336). ${ }^{2}$ Скорбут је редак код новорођенчади и најчешће се јавља код деце старе између 5. и 24. месеца, са највећом учесталошћу између 8 . и 10. месеца живота (Brickley and Ives 2006, 163; Ortner 2003, 384), код превремено рођених беба, беба са малом тежином при рођењу и близанаца (Lewis 2018, 214). ${ }^{3}$ Интерпретација специфичних лезија карактеристичних за скорбут проблематична је у перинаталном периоду, најпре због субпериосталне новоформиране ко-

\footnotetext{
${ }^{1}$ Петехије су тачке или пеге које се појављују на кожи услед поткожног крварења, а пурпуре представљају веће варијације патехија.

${ }^{2}$ Код новорођенчади и деце крварење примарно погађа покосницу, док је код одраслих крварење чешће у мишићима и виталним органима (Buckley et al. 2014, 73).

${ }^{3}$ Случајеви скорбута идентификовани код деце старости пет дана, повезују се са дијагнозама као што су неонатални или конгенитални скорбут, настао због неухрањености мајке током трудноће. Уколико је, нпр. трудница боловала од скорбута, односно имала неадекватну исхрану током трудноће, овај дефицит витамина може да се пренесе и на дете (Brickley et al. 2020, 49; Morrone et al. 2021). Новорођенчад која болују од скорбута склонија су развоју секундарних инфекција, које могу бити фаталне, али и застоју рада срца и анемији (Brickley et al. 2020, 49; Buckley et al. 2014, 74; Lewis 2018, 214).
} 


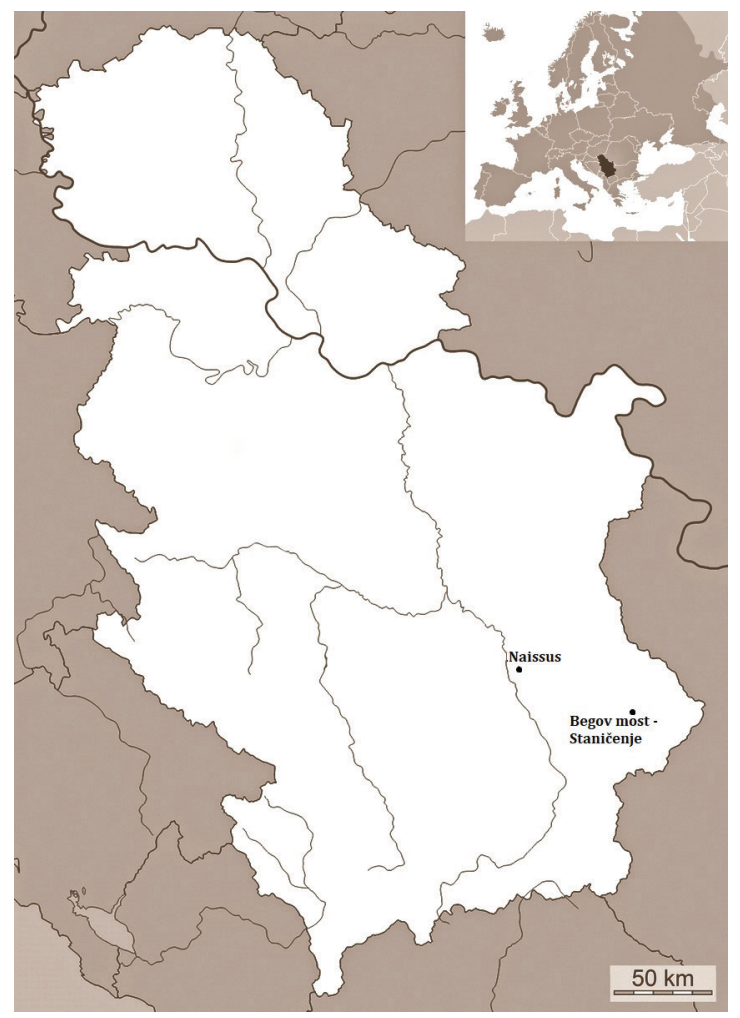

Карта 1. Положај археолошких налазишта на карти Републике Србије

Map 1. Location of archaeological sites on the map of the Republic of Serbia

сти која се очекује као последица нормалног раста кости (Lewis 2018, 132), а затим и због сличности патолошких промена које се уочавају код рахитиса, као и у случајевима коморбидитета или истовремене појаве ових и сличних обољења заједно (Morrone et al. 2021), ${ }^{4}$ и чињенице да је мало вероватно да би неухрањеном детету недостајао само један витамин (Morrone et al. 2021).

Ортнер и његови сарадници (Ortner et al. 1999, 323) дефинишу порозност која се јавља као последица скорбута, као локализовано, абнормално стање у коме фине рупице, видљиве без увећања или са малим увећањем, углавном мање од 1 мм у пречнику, продиру у компактну површину кости. ${ }^{5}$

\footnotetext{
${ }^{4}$ На скелету фетуса из гроба 108 (Дубље изнад куће, Нови Пазар) уочене су остеопоротичне лезије на спољашњој и унутрашњој површини костију лобање, на петрозној кости, на мандибули, као и на спољашњој површини ребара (T. I, 1). Ове лезије су највероватније последица неког метаболичког обољења попут скорбута, пре него нормалног развоја кости.

${ }^{5}$ Васкуларни форамени у кортикалној кости су нормална појава, међутим појављују се у знатно мањем броју на одређеној површини, различите су величине, углавном веће од 1 мм (Ortner et al. 2001, 344).
} 
Патолошке лезије представљају васкуларни одговор на хронично крварење због скорбута. Хронично крварење се јавља на местима где су крвни канали близу површине коже или су под стресом услед мишићне активности (контракција мишића је довољна да трауматизује већ оштећене крвне судове и узрокује хронично крварење [Jaffe 1972; Ortner et al. 2001, 344], што резултира продирањем и стварањем форамина у кортексу [Ortner et al. 1999, 322]). Скорбут се на кранијалном и посткранијалном скелету испољава у виду порозности и понекад је, али не увек, праћен је стварањем новоформиране кости на костима лобање (на фронталној кости, паријеталним, окципиталној, зигоматичним, сфеноидалној и темпоралним костима, на костима максила и на мандибули), на ребрима, на скапулама, на дугим костима руку и ногу и на илијачним костима. Иако се у литератури не спомињу тако често (Lovász et al. 2013, 179; Mahoney-Swales and Nystrom 2009, 39; Miladinović-Radmilović and Vulović 2015, 185, 193; Morrone et al. 2021, table 4; fig. 8; Vulović 2020, 34), jep нису главни индикатори болести (Schattmann 2014, 66; Schattmann et al. 2016, 66), лезије на спољашњој страни ребара су највероватније додатна манифестација скорбута. Управо због анатомије крвних судова, мишића и поткожне природе овог подручја, могуће је оштећење капилара и субпериостално крварење. Да су ове лезије на спољашњој страни ребара чест налаз код скорбута, имале смо прилике да видимо на скелетним остацима са више античких и средњовековних локалитета у Србији (Miladinović-Radmilović 2011; Miladinović-Radmilović and Vulović 2015, 185, 193; Vulović 2020, 34). ${ }^{6}$

\section{Болести доњег респираторног тракта}

Плућа су примарни органи респираторног система и обмотана су двослојном плућном марамицом (pleura). Површину плућних крила прекрива њен унутрашњи, висцерални лист (pleura viscelaris), а површину зидова марамичноплућног простора прекрива спољашњи, паријетални лист (pleura parietalis). Плеурална шупљина (cavum pleurae) простор је између ове две плеуре, односно, у питању је простор између плућа и унутрашњих површина ребара (сл. 1). Накупљање течности или гноја, као и запаљење у плеуралној шупљини, често узроковано болестима доњих дисајних путева, могу иницирати инфламаторну периосталну реакцију на унутрашњим површинама ребара (Davies-Barrett 2018, 14-20; Davies-Barrett et al. 2019, 1;

\footnotetext{
${ }^{6}$ На локалитету Маџарско брдо, у гробу 6, откривена је дечја индивидуа, стара око 6 месеци, са траговима скорбута (Т. I, 2). На локалитету Сингидунум, у гробу 1, откривена је дечја индивидуа, стара 3-4 године, са траговима скорбута (T. I, 3) (Miladinović-Radmilović and Vulović 2015, 193, Plate II, fig. 5).
} 


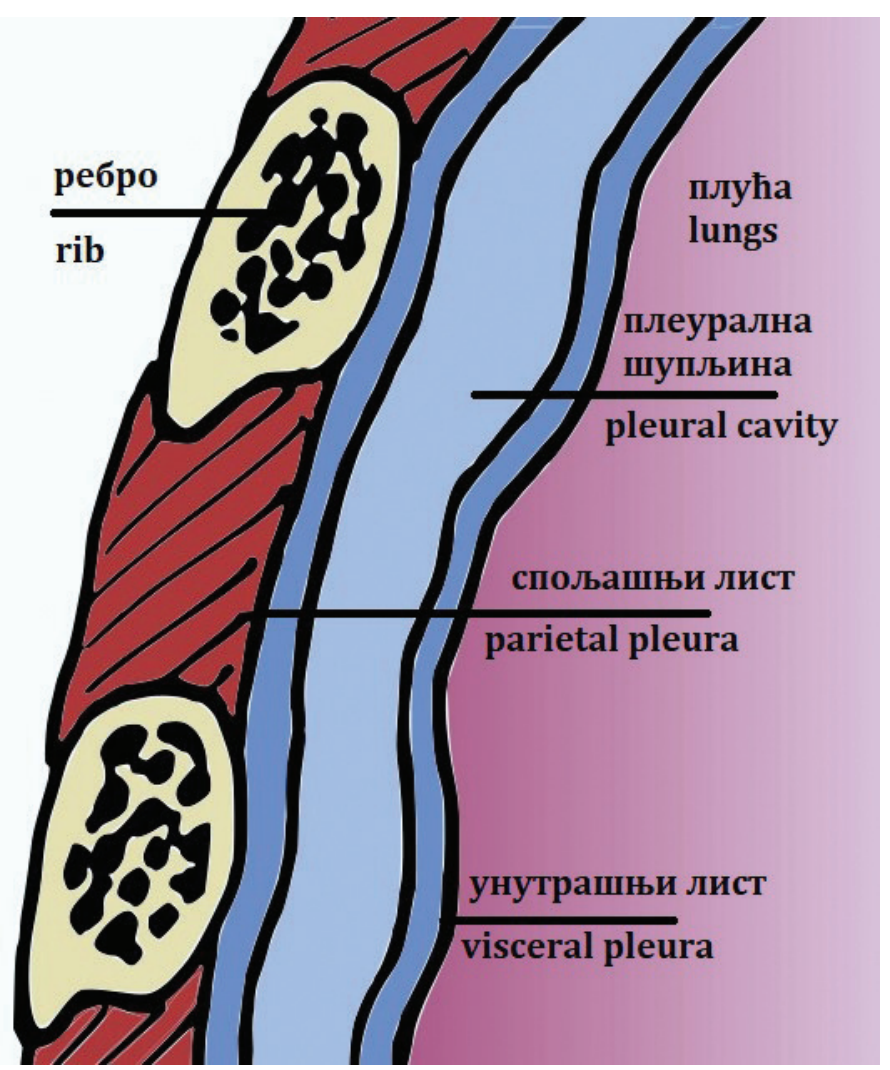

Сл. 1. Попречни пресек кроз грудни зид, где се види анатомска веза између ребара, плеура и плућа (Davies-Barrett 2018, figure 2.3, 17, модификовали аутори)

Fig. 1. Cross-section of the thoracic wall demonstrating the anatomical relationships between the ribs, pleurae, and lungs (Davies-Barrett 2018, figure 2.3, 17, modified by the authors)

Roberts et al. 1994, 171). У преантибиотско време, респираторне инфекције су биле узрочник великог броја смртних случајева код древних популација. Деца, старије особе, као и особе чији је организам већ био ослабљен услед других обољења (неухрањеност, трауме, системска обољења, генетске болести $)^{7}$ нарочито су подложне патогенима који нападају респираторни систем, а код прогресивних облика ових болести, односно доњег респираторног тракта, плеурална инфекција може да захвати и унутрашњу страну ребара. Присуство периосталне реакције, која доводи до стварања новоформиране кости на унутрашњој страни ребара констатована је на људским скелетним

\footnotetext{
7 До респираторних инфекција долази и због загађеног ваздуха у просторијама где се живи, лоших климатских услова, али и приликом обављања одређених врста послова (нпр. рударство, топљење метала, итд.) (Bernovsky 2010, 52).
} 
остацима из различитих временских периода и са различитих географских подручја (Baker et al. 2015; Davies-Barrett 2018; Lambert 2002; Matos and Santos, 2006; Mays et al. 2002; Molto 1990; Nicklisch et al. 2012; Pfeiffer 1991; Pósa, et al. 2013; Roberts and Buikstra 2003; Roberts et al. 1994; Roberts et al. 1998; Santos and Roberts, 2006; Wakely et al. 1991, итд.). У клиничкој пракси, најчешће респираторне инфекције које изазивају запаљење плеуре укључују туберкулозу, пнеумонију и актиномикозу (Kass et al. 2007). Радиолошке студије на савременој популацији са плућним обољењима (Eyler et al. 1996; Guttentag and Salwen 1999), забележиле су појаву задебљања на ребрима, посебно код људи са туберкулозом, што указује управо на новоформирану кост. Периосталне лезије на ребрима, акумулација течности и потенцијално запаљење плеуре, такође су документоване и код других обољења као што су упала плућа, бронхопнеумонија, плућна емболија, хронични бронхитис, тумори, срчана обољења, обољење бубрега, инфекције и трауме (Davies-Barrett et al. 2019, 2; Matos and Santos 2006, 198; Nicklisch et al. 2012, 396; Santos and Roberts 2006, 47). Инфекције настају углавном због бактерија (pneumococci и mycobacteria), међутим, гљивице, паразити и вирусне инфекције, такође, могу бити њени узрочници (Nicklisch et al. 2012, 396-397).

Туберкулоза је инфективно обољење, које узрокује бактерија из Mycobacterium tuberculosis комплекса (M. tuberculosis, M. bovis, M. caprae, M. canettii, M. microti, и M. africanum), а примарно погађа мека ткива, да би се касније проширила и на скелет (Aufderheide and Rodríguez-Martín 1998, 118; Ortner 2003, 227). Преноси се са човека на човека (од заражене особе се ваздухом шири капљичним путем), или преко контакта са стоком, односно конзумирањем зараженог меса, млека и млечних производа (Roberts and Buikstra 2003, 88; Roberts et al. 1994, 169). Најчешћи узрочник туберкулозе код људи је M. tuberculosis, мада човек може да се зарази и преко M. bovis и M. caprae (Roberts 2012, 435). Развој инфекције зависи од патогена као и од имуног одговора оболелог. Код човека туберкулоза може бити хронична и акутна, на меким ткивима и/или на костима (Aufderheide and Rodríguez Martín 1998, 118). Када бацил доспе у тело, инфекција се хематогеним путем шири од плућа ка другим органима и ка костима, међутим, само мали проценат (3-5\%) инфицираних индивидуа ће развити те промене на костима (Roberts and Buikstra 2003, 89). У многим случајевима, туберкулоза остаје невидљива приликом макроскопског испитивања скелета, посебно уколико особа умре убрзо након инфекције и пре него што су се испољили знаци на костима (Santos 2015, 109). Од осамдесетих година прошлог века расте интересовање за међусобну везу између стварања новоформиране кости 
на унутрашњој страни ребара и респираторних обољења, посебно плућне туберкулозе. Улогу новоформиране кости на унутрашњој површини ребара у дијагнози туберкулозе код древних популација истраживали су многи истраживачи, и на скелетним остацима из археолошког контекста (Davies-Barrett 2018; Davies-Barrett et al. 2019; Lambert 2002; Nicklisch et al. 2012; Roberts and Buikstra 2003, итд.), и на скелетним остацима из великих скелетних серија са познатим узроцима смрти (Kelley and El-Najjar 1980; Kelley and Micozzi 1984; Matos and Santos 2006; Roberts et al. 1994; Roberts et al. 1998; Santos and Roberts 2001; idem. 2006; Spekker 2018, итд.). Проучавање релативно савременог скелетног материјала, са документованим узроцима смрти, доста је помогло у разјашњавању улоге лезија на ребрима и дијагностиковања плућне туберкулозе. Мало је клиничких студија о лезијама на ребрима, односно о стварању новоформиране кости на унутрашњој страни ребара, и њиховој вези са плућним обољењима, због тога што ове промене нису примарне у дијагностици и зато што се само дубоки слојеви новоформиране кости виде на рендгенским снимцима. Наведене студије показују позитивну корелацију између периостозе на ребрима и инфекције бацилом Mycobacterium tuberculosis, иако је јасно из ових али и других студија да известан број других обољења (попут пнеумоније) потенцијално може да стимулише одговор остеобласта (Lambert 2002, 282). Лезије на ребрима су посматране у оквиру пет стадијума (0-4), које су дефинисали Никлиш и њени сарадници (Nicklisch et al. 2012). Сваки од стадијума показује разлику у изгледу, структури и интезитету деструктивних појава:

Стадијум 1 - уочавају се благе периосталне реакције на ребрима, али без стварања новоформиране кости;

Стадијум 2 и 3 - патолошке промене су присутне на ребрима са благим до израженим стварањем новоформиране кости (T. II, 3) и

Стадијум 4 - на ребрима се уочава веома изражено стварање новоформиране кости са литичким лезијама (Т. I, 4- 5; Т. II, 2).

\section{Методолошки оквири}

Током вишегодишњег рада на скелетном материјалу дечјих индивидуа из античког и средњовековног периода у Србији, приметиле смо ову врсту лезија на ребрима (T. I, 1-3), а у даљем тексту ћемо приказати три специфична случаја са два касноантичка локалитета из Србије: Naissus, локалитет Јагодин мала - Булевар војводе Мишића (Ниш), и Бегов мост - Станичење (околина Пирота, Градиште) (Карта 1). На истраженом делу некрополе на локалитету Јагодин мала - Булевар војводе Мишића, који припада периоду 
4-5. века (Jeremić i Čerškov 2016, 130), укупно су истражене 33 гробне целине, док је за анализу било доступно 49 индивидуа (17 дечјих [34,7\%] и 32 јувенилне и одрасле индивидуе $[65,3 \%])$. Током истраживања некрополе на локалитету Бегов мост - Станичење, која се датује у другу половину 4-6. века (Petković i dr. 2017, 124), констатоване су 132 гробне целине, док је за анализу било доступно 128 индивидуа (55 дечјих [43\%] и 73 јувенилне и одрасле индивидуе [57\%]). Утврђивање индивидуалне старости код дечјих индивидуа вршено је на основу: степена формирања и ерупције зуба (Buikstra and Ubelaker 1994: 51), дужине дугих костију према табелама са временским распонима у месецима и годинама (Bass 1995, 155, 168, 176, 228, 247, 257; Ferembach et al. 1980, 532; Scheuer and Black 2000) и степена окоштавања епифизно-дијафизних спојева према табели са временским распонима у годинама, у којима исти окоштавају (Ferembach et al. 1980, 531).

С обзиром на то да смо желели да посматрамо конкретне разлике у испољавању ових лезија на ребрима код скорбута и плућних обољења, односно туберкулозе, у анализу су укључени само они скелети који су имали довољно елемената за посматрање оба обољења. За посматрање скорбута нужно је присуство кранијалног скелета (као што смо већ напоменуле, скорбут се испољава на следећим костима кранијалног скелета: на фронталној, паријеталним, окципиталној, зигоматичним, сфеноидалној и темпоралним костима, на костима максила и на мандибули [Brickley et al. 2020, 53; Ortner 2003, 384; Ortner et al. 1999; Ortner et al. 2001]), те уколико испитивана индивидуа није имала довољно очуваних коштаних елемената за успостављање дијагнозе скорбута, морала је бити искључена из анализе. Такође, било је потребно и да све испитиване индивидуе, поред очуваног кранијума, имају и очувана ребра за посматрање ових промена (Lambert 2002; Nicklisch et al. 2012; Roberts and Buikstra 2003, 103-104; Spekker 2018, 22-23). Тако је првобитно планиран узорак од 17 дечјих индивидуа са локалитета Јагодин мала - Булевар војводе Мишића и 55 дечјих индивидуа са локалитета Бегов мост - Станичење ограничен на десет скелета са Јагодин мале и 34 скелета са Беговог моста, за анализу метаболичких обољења, односно скорбута, док је за анализу промена на ребрима узето у обзир седам скелета са локалитета Јагодин мала - Булевар војводе Мишића и 36 скелета са локалитета Бегов мост - Станичење. На крају, како би се испоштовали сви критеријуми очуваности скелетних елемената, за анализу је било доступно свега шест скелета са локалитета Јагодин мала - Булевар војводе Мишића и 28 скелета са локалитета Бегов мост - Станичење. Испитивање је спроведено макроскопски под увећавајућом лупом и јаким светлом. 
Први случај, локалитет Бегов мост - Станичење. У гробу 14, откривена је дечја индивидуа стара 9-12 месеци. На кранијалном скелету поротичне лезије су уочене на: костима калоте (порозна хиперостоза), на костима орбита (cribra orbitalia), али и на мандибули и на темпоралним костима. Поротичне лезије на посткранијалном скелету приметне су биле на дугим костима руку и ногу, и на илијачним костима. Поротичне лезије на ребрима су откривене са спољашње стране (T. II, 1-2). Диференцијална дијагноза је скорбут.

Други случај, локалитет Бегов мост - Станичење. У гробу 74, откривена је дечја индивидуа стара 3-6 месеци. На кранијалном скелету поротичне лезије су уочене на: костима калоте (порозна хиперостоза), на сфеноидалној кости и на темпоралним костима. Поротичне лезије на посткранијалном скелету приметне су биле на дугим костима руку и ногу, и на илијачним костима. Поротичне лезије, стварање новоформиране кости и периостоза на ребрима откривени су са унутрашње стране (T. II, 3). Диференцијалне дијагнозе су скорбут и туберкулоза.

Трећи случај, локалитет Јагодин мала - Булевар војводе Мишића. У гробу 13, откривена је дечја индивидуа стара око 10 година. Новоформирана кост, периостоза, праћена плитким и кружним деструктивним литичким лезијама откривене су на унутрашњој страни ребара (Т. I, 4-5; Т. II, 4). На пршљеновима је са антериорне стране била приметна и ресорпција ткива. Диференцијална дијагноза је туберкулоза.

\section{Дискусија и закључак}

У палеопатолошкој литератури једине описане промене на ребрима, које су последица скорбута, јесу проширења ребарно-хрскавичних спојева, настала као одговор на хронично крварење (Aufderheide and Rodríguez-Martín 1998, 311; Brickley and Ives 2006, 170; Brickley and Mays 2019, 532; Ortner 2003, 386), док се са друге стране порозност дуж латералне површине тела ребара не спомиње. ${ }^{8}$ Иако Mahoney-Swales и Nystrom спомињу да билатерално присутна порозност на латералним површинама ребара може да буде узрокована и повијањем детета, при чему је могло да дође до стреса и пуцања осетљивих крвних судова, ипак сматрају да су ове лезије још један од симптома дефицита витамина Це и скорбута (Mahoney-Swales and Nystrom 2009, 34, 39). Тако су од 12 индивидуа са локалитета Бегов мост - Станичење, код којих је констатован скорбут, код четири индивидуе видљиве лезије на спољашњим странама ребара, једна индивидуа је имала

${ }_{8}^{8}$ У случајевима рахитиса, порозност се јавља при стерналним окрајцима ребара (Brickey and Mays 2019, 544). 
новоформирану кост са унутрашње стране ребара, док код седам нису биле видљиве лезије. Једна индивидуа која није имала скорбут имала је лезије и на спољашњој страни ребара. Лоша очуваност остеолошког материјала дечјих индивидуа са локалитета Јагодин мала - Булевар војводе Мишића, као и мала учесталост скорбута онемогућила је боље сагледавање ове појаве на овом локалитету (две индивидуе код којих је констатован скорбут нису имале лезије на ребрима).

Лезије на ребрима, карактеристичне за болести доњег респираторног тракта и туберкулозе чешће се јављају са леве стране тела (однос 2:1), са највећом учесталошћу између 4. и 8. peбра (Kelly and Micozzi 1984, 382). Нажалост, због лоше очуваности остеолошког материјала није било могуће видети која ребра су и у коликом броју су захваћена периостозом. Код индивидуе сахрањене у гробу Г-74 на локалитету Бегов мост - Станичење, поред лезија присутних на кранијалном и посткранијалном скелету карактеристичних за скорбут, видљива је и новоформирана кост на унутрашњој страни ребара, која може да укаже да је ова дечја индивидуа патила и од хроничне болести доњег респираторног тракта, највероватније туберкулозе, мада није искључено да би диференцијална дијагноза могла да буде и хронично запаљење плућа и дуготрајни бронхитис, услед ослабљености организма и смањене имунолошке отпорности изазване скорбутом и недостатком витамина Це (Vulović 2020, 121). ${ }^{9}$ Лезије на ребрима одговарају 3. стадијуму, према скоринг систему који су развили Никлиш и њени сарадници (Nicklisch et al. 2012, 394). То свакако није усамљен случај да се код једне особе у исто време дијагностикују скорбут и туберкулоза (Geber 2019, 182; Miladinović-Radmilović and Vulović 2015; Miladinović-Radmilović and Petković 2020, 250; Миладиновић-Радмиловић и Бикић, у штампи; Rimpf and Novak 2020; Trupković et al. 2012). Код дечје индивидуе сахрањене у гробу Г-13 на локалитету Јагодин мала - Булевар војводе Мишића, на унутрашњој површини ребара обе стране тела, констатоване су новоформирана кост и деструктивне литичке лезије, које по Никлиш скоринг систему одговарају 3. и 4. стадијуму (Nicklisch et al. $2012,394)$. Примећене су и лезије на антериорним странама тела пршљенова, у виду ресорпције коштаног ткива. Различита су мишљења по питању ових промена на пршљеновима. Док поједини аутори сматрају да су промене у вези са раном фазом туберкулозе кичменог стуба (Hlavenková 2019: 106;

\footnotetext{
${ }^{9}$ Иако постоје студије у којима је рађена идентификација ДНК туберкулозе на скелетима који су имали ове промене на унутрашњој површини ребара (Mays et al. 2002; Nicklisch et al. 2012), само присуство ДНК не мора да значи да је туберкулоза изазвала ове лезије, те поједини истраживачи предлажу да се присуство ових лезија посматра као генерални индикатор присуства респираторних болести (Lambert 2002, 283; Pfeiffer 1991, 197).
} 
Kyselicová et al. 2016: 22; Mays et al. 2002: 31; Миладиновић-Радмиловић и Бикић in press, Miladinović-Radmilović and Vulović 2015: 185), други сматрају да нису, већ представљају искључиво анатомски варијетет васкуларизације тела пршљенова (Barnes 2012: 103; Јановић и др. 2017: 74-75). Друге патолошке промене на костима нису примећене, мада је скелет био лошије очуван. Новоформирана кост праћена литичким лезијама јавља се и на скелетима из археолошког контекста и на скелетима из добро познатих савремених скелетних серија (Davies-Barrett 2018; Dawson and Brown 2012; Hlavenková et al. 2015; Kelly and Micozzi 1984; Lambert 2002; Matos and Santos 2006; Molto 1990; Mays et al. 2002; Nicklisch et al. 2012; Pfeiffer 1991; Roberts and Buikstra 2003; Roberts et al. 1998; Santos and Roberts 2006, итд.).

Као што је приказано у тексту, постоји јасна разлика у начину испољавања периосталне реакције на ребрима. Појава лезија на спољашњој страни ребара последица је скорбута, а на унутрашњој страни последица је хроничних и дуготрајних респираторних проблема. Приликом обраде овог материјала нисмо приметиле да се код деце на спољашњој страни ребара јавља новоформирана кост у виду скраме, која је уочена на унутрашњој површини ребара. Када су у питању одрасле индивидуе, на унутрашњој површини ребара чешће се срећу промене које одговарају првом стадијуму Никлишовог скоринг система, и лезије које би више указивале на залечену фазу болести. За разлику од тога, овде приказане промене у виду новоформиране кости које су праћене литичким лезијама, јасно указују да је болест била активна у тренутку смрти индивидуа. Због свега наведеног приликом антрополошке анализе потребно је јасно описати место и сам изглед лезија, као и, уколико је могуће, забележити на којим ребрима се лезије јављају, како би успостављање тачне дијагнозе и интерпретације резултата анализе били прецизнији.

\section{БИБЛИОГРАФИЈА}

Assis, S. and Keenleyside A. 2019. The macroscopic and histomorphological properties of periosteal rib lesions and its relation with disease duration: evidence from the Luis Lopes Skeletal Collection (Lisbon, Portugal). Journal of Anatomy 234 (4): 480-501.

Aufderheide, A. and Rodríguez-Martín, C. 1998. The Cambridge Encyclopaedia of Human Paleopathology. Cambridge: University Press.

Baker, O., Lee, O., Wu, H., et al. 2015. Human tuberculosis predates domestication in ancient Syria. Tuberculosis 95 (1): s4-s12.

Barnes, E. 2012. Atlas of Developmental Field Anomalies of the Human Skeleton: A Paleopathology Perspective. Hoboken, New Jersey: John Wiley \& Sons, Inc. 
Bass, W. 1995. Human Osteology, A Laboratory and Field Manual. Columbia: Missouri Archaelogical Society.

Bernofsky, K. S. 2010. Respiratory health in the past: a bioarchaeological study of chronic maxillary sinusitis and rib periostitis from the Iron Age to the Post Medieval Period in Southern England. Durham theses, Durham University. Available at Durham E-Theses Online: http://etheses.dur.ac.uk/614/

Bisseret, D., Kaci, R., Lafage-Proust, M-H., Alison, M., Parlier-Cuau, C., Laredo, J-D. and Bousson, V. 2015. Periosteum: Characteristic imaging findings with emphasis on radiologic-pathologic comparisons. Skeletal Radiology 44: 321-338.

Bourbou, C. 2014. Evidence of childhood scurvy in a Middle Byzantine Greek populationfrom Crete, Greece (11th-12th centuries A.D.). International Journal of Paleopathology 5: 86-94.

Brickley, M. and Ives, R. 2006. Skeletal Manifestations of Infantile Scurvy. American Journal of Physical Anthropology 129: 163-172.

Brickley, M., Ives, R. and Mays, S. 2020. The Bioarchaeology of Metabolic Bone Disease. Second edition. Oxford: Elsevier.

Brickley, M. and Mays, S. 2019. Metabolic Disease, in: J. E. Buikstra (ed.), Ortner's Identification of Pathological Conditions in Human Skeletal Remains (3rd ed.). London: Academic Press, 531-566.

Buckley, H. R., Kinaston, R., Halcrow, S. E., Fostera, A., Spriggs, M. and Bedford, S. 2014. Scurvy in a tropical paradise? Evaluating the possibility of infant and adult vitamin C deficiency in the Lapita skeletal sample of Teouma, Vanuatu, Pacific islands. International Journal of Paleopathology 5: 72-85.

Buikstra, J. and Ubelaker, D. 1994. Standards for data collection from human skeletal remains. Arkansas Archeological Survey Research Series, No 44. Fayettville, Arkansas: Arkansas Archeological Survey.

Vulović, D. 2020. Fzičko-antropološke karakteristike stanovnika urbanih i ruralnih naselja provincije Sredozemne Dakije IV-VII veka. Filozofski fakultet, Univerzitet u Beogradu. Doktorska disertacija.

Geber J. 2019. Suffering the Great Hunger: Scurvy and Tuberculosis as Reflected in Skeletons of Victims of the Great Irish Famine (1845-1852), in: Preedy V., Patel V. (eds) Handbook of Famine, Starvation, and Nutrient Deprivation. Springer, Cham. 171-189.

Guttentag, A. R. and Salwen, J. K. 1999. Keep your eyes on the ribs: the spectrum of normal variants and diseases that involve the ribs. Radiographics 19: 1125-1142.

Davies-Barrett, A. M. 2018. Respiratory disease in the Middle Nile Valley: a bioarchaeological analysis of the impact of environmental and sociocultural change from the Neolithic to Medieval periods. Doctoral dissertation. Department of Archaeology, Durham University, Department of Ancient Egypt and Sudan, The British Museum.

Davies-Barrett, A. M., Antoine, D. and Roberts, C. 2019. Inflammatory periosteal reaction on ribs associated with lower respiratory tract disease: A method for recording prevalence from sites with differing preservation. American Journal of Physical Anthropology 168 (3): 530-542. 
Dawson, H. and Brown, K. R. 2012. Childhood tuberculosis: A probable case from late mediaeval Somerset, England. International Journal of Paleopathology 2: 3-35.

De Silva, P., Evans-Jones, G., Wright, A. and Henderson, R. 2003. Physiological periostitis; a potential pitfall. Archives of Diseases in Childhood 88: 1124-1125.

Ђурић-Срејић, М. 1995. Увод у физичку антропологију древних популаџија. Београд: Завод за уџбенике и наставна средства.

Edeiken, J., Hodes, P. and Caplan, L. 1966. New bone production and periosteal reaction. American Journal of Roentgenology 97: 708-718.

Eyler, W. R., Monsein, L. H., Beute, G. H., Tilley, B., Schultz, L. R. and Schmitt, W. G. H. 1994. Rib enlargement in patients with chronic pleural disease. American of Journal Radiology 167: 921-926.

Јановић, А., Павићевић, П. и Ђурић, М. 2017. Неуобичајени отвори на површини пршљенских тела: анатомски варијетет или знак патолошких промена, у: Српско археолошко друштво, XL Скупштина и годишњи скуп и прослава 70 година Археолошког института (Mnетоsynon Firmitatis), Београд 5-7. јун 2017, ур. А. Црнобрња, В. Филиповић, Београд 2017, 74-75.

Jaffe, H. L. 1972. Metabolic degenerative and inflammatory diseases of bones and joints. Philidelphia: Lea \& Febiger.

Jeremić, J. i Čerškov, T. 2016. Requescit in pace - neka zapažanja o poremećajima „večnog počinka” na primeru jugoistočnog dela nekropole u Jagodin Mali (Naissus), u: Bioarchaeology in Balkans. Methodological, comparative and reconstructive studies of life in the past. Papers of the Bioarchaeological section of The Serbian Archaeological Society (Bioarheologija na Balkanu. Metodološke, komparativne i rekonstruktivne studije života u prošlosti. Radovi Bioarheološke sekcije Srpskog arheološkog društva), Eds. N. Miladinović-Radmilović and S. Vitezović, Srpsko arheološko društvo, Blago Sirmijuma, Beograd - Sremska Mitrovica 2016, 127-145.

Kass, S. M., Williams, P. M., and Reamy, B. V. 2007. Pleurisy. American Family Physician 75: 1357-1364.

Kelley, M. A. and El-Najjar, M. Y. 1980. Natural Variation and Differential Diagnosis of Skeletal Changes in Tuberculosis. American Journal of Physical Anthropology 52:153-167. Kelley, M. A. and Micozzi, M. S. 1984. Rib lesions in chronic pulmonary tuberculosis. American Journal of Physical Anthropology 65: 381-386.

Kyselicová, K., Šebest, L., Beňuš, R., Bognár, C. and Dörnhöferová, M. 2016. Anthropological evaluation of early skeletal tuberculosis in the medieval population of Devín-Castle (11th-12th century ad., Slovakia). Česká antropologie 66/2: 20-25.

Lambert, P. 2002. Rib lesions in a prehistoric Puebloan sample from Southwestern Colorado. American Journal of Physical Anthropology 117: 281-292.

Lewis, M. 2018. Paleopathology of Children. Identification of Pathological Conditions in the Human Skeletal Remains of Non-Adults.1st Edition. Academic Press.

Lovász, G., Schultz, M., Gödde, J., Bereczki, Z., Pálfi G., Marcsik, A. and Molnár, E. 2013. Skeletal manifestations of infantile scurvy in a late medieval anthropological series from Hungary. Anthropological Science 121 (3): 173-185. 
Mahoney-Swales, D. and Nystrom, P. 2009. Skeletal manifestation of non-adult scurvy from early medieval Northumbria: the Black Gate cemetery, Newcastle-upon-Tyne. In: Lewis, M. and Clegg, M. (Eds.), Proceedings of the Ninth Annual Conference of the British Association for Biological Anthropology and Osteoarchaeology. BAR International Series 1981, Archaeopress, Oxford, 31-41.

Matos, V. and Santos, A. L. 2006. On the trail of pulmonary tuberculosis based on rib lesions: Results from the human identified skeletal collection from the Museu Bocage (Lisbon, Portugal). American Journal of Physical Anthropology 130: 190-200.

Mays, S., Fysh, E. and Taylor, G. M. 2002. Investigation of the Link Between Visceral Surface Rib Lesions and Tuberculosis in a Medieval Skeletal Series From England Using Ancient DNA. American Journal of Physical Anthropology 119: 27-36.

Miladinović-Radmilović, N. 2011. Sirmium - Necropolis. Beograd: Arheološki institut, Sremska Mitrovica: Blago Sirmijuma.

Miladinović-Radmilović, N. and Vulović, D. 2015. The case of scurvy from Singidunum. Старинар LXV/2015: 183-195.

Miladinović-Radmilović, N. and Petković, S. 2020. Health and social status of children in the ancient Timacum Miinus, in: I. Popović and S. Petković (eds), Illyricvm Romanvm. Studiola in honorem Miloje Vasić, Belgrade, 240-267.

Миладиновић-Радмиловић, Н. и Бикић, В. Смрт и сахрана на почетку новог доба - некропола на налазишту Бубањ код Ниша, in press.

Molto, J. E. 1990. Differential Diagnosis of Rib Lesions: A Case Study From Middle Woodland Southern Ontario Circa 230 A.D. American journal of Physical Anthropology 83: 439-447.

Morrone, A., Tõrv, M., Piombino-Mascali, D., Malve, M., Valk, H. and Oras, E. 2021. Hunger, disease and subtle lesions: insights into systemic metabolic disease in fetal and perinatal remains from 13th-15th century Tartu, Estonia. International Journal of Osteoarchaeology, doi:10.1002/oa.2970.

Nicklisch, N., Maixner, F., Ganslmeier, R., Friederich, S., Dresely, V., Meller, H., Zink, A. and Alt, K. W. 2012. Rib Lesions in Skeletons From Early Neolithic Sites in Central Germany: On the Trail of Tuberculosis at the Onset of Agriculture. American Journal of Physical Anthropology 149: 391-404.

Ortner, D. 2003. Identification of Pathological Conditions in Human Skeletal Remains (second edition). Amsterdam, Boston, London, New York, Oxford, Pariz, San Diego, San Francisco, Singapure, Sydney, Tokyo: Academic Press.

Ortner, D. J., Kimmerle, E. H. and Diez, M. 1999. Probable Evidence of Scurvy in Subadults from Archaeological Sites in Peru. American Journal of Physical Anthropology 108: 321-331.

Ortner, D., Butler, W., Cafarella, J. and Milligan, L. 2001. Evidence of Probable Scurvy in Subadults from Archaeological Sites in North America. American Journal of Physical Anthropology 114: 343-351. 
Petković S., Mitić M. i Jović M. 2017. Begov most - Staničenje, zaštitna arheološka iskopavanja u 2014. godini na trasi autoputa E80, Koridor 10 - istočni krak, u I. Bugarski, N. Gavrilović Vitas, V. Filipović (ur.) Arheologija u Srbiji: projekti Arheološkog instituta u 2014. godini, Beograd, Arheološki institut: 121-126.

Pósa, A., Maixner, F., Lovász, G. et al. 2013. Revision of tuberculous lesions in the Bácsalmás-Óalmás series - preliminary morphological and biomolecular studies. Anthropologischer Anzeiger 70 (1): 83-100.

Pfeiffer, S. 1991. Rib lesions and New World tuberculosis. International Journal of Osteoarchaeology 1: 191-198.

Rana, R., Wu, J. and Eisenberg, R. 2009. Periosteal reaction. American Journal of Roentgenology 193: w259-w272.

Rimpf, A. and Novak, M. 2020. Evliya Çelebi and the town cemetery of Ilok, in: Life and death in mediaeval and early modern times. Proceedings of the 5th International Scientific Conference of Mediaeval Archaeology of the Institute of Archaeology Zagreb, Krznar, S., Sekelj Ivančan, T., Belaj, J. and Tkalčec, T. (eds.). Zagreb: Institut za arheologiju, 239-260.

Roberts, C. 2012. Re-Emerging Infections: Developments in Bioarchaeological Contributions to Understanding Tuberculosis Today, in: A. L. Grauer (ed), A companion to paleopathology. Wiley-Blackwell: 434-457.

Roberts, C. A. and Buikstra, J. E. 2003. The bioarchaeology of tuberculosis: A global view on a reemerging disease. Gainesville: University Press of Florida.

Roberts, C. A., Lucy, D. and Manchester, K. 1994. Inflammatory lesions of ribs: An analysis of the Terry Collection. American Journal of Physical Anthropology 95: 169-182. Roberts, C. A., Boylston, A., Buckley, L., Chamberlain, A. C. and Murphy, E. M. 1998. Rib lesions and tuberculosis: The palaeopathological evidence. Tubercle and Lung Disease 79 (1): 55-60.

Santos, A. L. 2015. Archives and skeletons: An interdisciplinary approach to the study of paleopathology of tuberculosis. Tuberculosis 95: 109-111.

Santos, A. L. and Roberts, C. A. 2001. A picture of tuberculosis in young Portuguese people in the early 20th century. American Journal of Physical Anthropology 115: 38-49. Santos, A. L. and Roberts, C. A. 2006. Anatomy of a serial killer: Differential diagnosis of tuberculosis based on rib lesions of adult individuals from the Coimbra Identified Skeletal Collection, Portugal. American Journal of Physical Anthropology 130: 38-49.

Spekker, O. 2018. Evaluation of endocranial bony changes in relation to tuberculosis in the Robert J. Terry anatomical skeletal collection (Washington, DC, USA). Department of Biological Anthropology, Faculty of Science and Informatics, University of Szeged. Doctoral dissertation.

Shopfner, C. E. 1966. Periosteal bone growth in normal infants. A Preliminary Report 97 (1): 154-163.

Schattmann, A. 2014. The Co-Occurrence of Scurvy and Rickets in 16th to 18th Century Skeletal Material from Douai, France. MA Thesis, McMaster University. 
Schattmann, A., Bertrand, B., Vatteoni, S. and Megan Brickley, M. 2016. Approaches to co-occurrence: Scurvy and rickets in infants and youngchildren of 16-18th century Douai, France. International Journal of Paleopathology 12: 63-75.

Scheuer, L. and Black, S. 2000. Developmental Juvenile Osteology. London: Academic Press.

Trupković, M., Rajić Šikanjić, P. and Premužić, Z. 2012. A case of childhood tuberculosis from the site of St. Martin`s square in Umag. Histria archaeologica 42: 233-243. Ferembach, D., Schwidetzky, I. and Stloukal, M. 1980. Recommendations for age and sex diagnosis of skeletons. Journal of Human Evolution 7: 517-549.

Hlavenková, L. 2019. Nemoci v populacích řimského období z hlediska paleopatologie. [Diseases in populations from the Roman period in terms of palaeopathology]. Praha, 2019. 216 s., príloha 7 s. Dizertačná práca. Univerzita Karlova, 1. lékařská fakulta, Ústav dějin lékařství a cizích jazyků 1. LF UK. Školitel’ záverečnej práce: prof. MUDr. Václav Smrčka, CSc.

Hlavenková, L., Teasdale, M. D., Gábor, O., Nagy, G., Beňuš, R., Marcsik, A., Pinhasi, R. and Hajdu, T. 2015. Childhood bone tuberculosis from Roman Pécs, Hungary. HOMO - Journal of Comparative Human Biology 66: 27-37.

Wakely, J., Manchester, K. and Roberts, C. 1991. Scanning electron microscopy of rib lesions. International Journal of Osteoarchaeology 1: 185-189.

Waldron, T. 2009. Palaeopathology. Cambridge University Press, Cambridge.

Weston, D. 2008. Investigating the specificity of periosteal reactions in pathology museum specimens. American Journal of Physical Anthropology 137 (1): 48-59.

Weston, D. 2012. Nonspecific Infection in Paleopathology: Interpreting Periosteal Reactions, in: A. L. Grauer (ed.), A companion to paleopathology. Wiley-Blackwell: 492-512. 


\section{Dragana Vulović}

Institute of Archaeology, Belgrade

Nataša Miladinović-Radmilović

Institute of Archaeology, Belgrade

\section{POSSIBLE REASONS FOR THE OCCURRENCE OF PERIOSTEAL REACTON ON RIBS OF CHILDREN INDIVIDUALS IN ARCHAEOLOGICAL CONTEXTS}

Keywords: periosteal reaction, ribs, scurvy, tuberculosis, Jagodin Mala, Begov Most

Periosteal reaction in the form of porotic lesions or a new bone formation is not a common finding on ribs of children individuals from archaeological contexts. Those lesions occur on both the outer and the inner surface of ribs ( $\mathrm{T}$. I, T. II), and aside from the actual location of the lesions and their morphological aspect, a difference can be noted in the differential diagnosis as well. Periosteal reaction and new bone formation are a common clinical finding in the entire spectre of pathological conditions such as traumas, infections, bleeding, metabolic diseases, tumors, vein problems, development disorders, endocrine disorders, but they are also present in cases of a normal development of bones as well. The most common cause of these lesions are metabolic diseases (such as scurvy) and diseases of the lower respiratory tract and lung diseases (i.e. tuberculosis). Scurvy is a metabolic disease caused by vitamin $\mathrm{C}$ deficiency and is characterised by specific changes on bones of the cranial and postcranial skeleton. When it comes to lung diseases (pneumonia, bronchitis, cancer, lung tuberculosis), specific changes can occur on the inner side of the ribs, which indicate that the disease of the lower respiratory tract spread directly through pleura and onto the surface of the ribs (Fig. 1). Tuberculosis is a specific infectious disease, caused by a bacteria from the Mycobacterium tuberculosis complex, and which is also followed, in the final stages of the disease, by characteristic changes on the skeleton, among others, changes on the inner side of the ribs as well. We examined the lesions on skeletons of children individuals discovered at two Late Antique site in Serbia: Naissus, the site of Jagodin Mala - Bulevar Vojvode Mišića, and at the site of Begov Most - Staničenje (Map 1).

The only changes on ribs that were the consequence of scurvy described in the paleopathological literature are widenings of the costo-cartilage junctions, occurring as a response to chronic bleeding (Aufderheide and Rodríguez-Martín 1998, 311; Brickley and Ives 2006, 170; Brickley and Mays 2019, 532; Ortner 
2003, 386), while, on the other hand, porosity along the lateral surfaces of the body of ribs isn't mentioned. Even though Mahoney-Swales and Nystrom mention that bilaterally present porosity on lateral surfaces of ribs can also be caused by the swaddling of the child, when stress and rupture of sensitive blood vessels could have occurred, they still believe that these lesions were another symptom of vitamin C deficiency and scurvy (Mahoney-Swales and Nystrom 2009, 34, 39). Out of 12 individuals from the site of Begov Most - Staničenje for which it was determined that they had scurvy, four individuals had visible lesions on outer sides of ribs (T. II, 1-2). Poor preservation level of the osteological material of children individuals from the site of Jagodin Mala - Bulevar Vojvode Mišića, as well as the low incidence of scurvy, prevented us for getting a better overview of this occurrence on this site.

Lesions on ribs, typical for the diseases of the lower respiratory tract and tuberculosis, occur more commonly on the left side of the body, with the highest incidence between the $4^{\text {th }}$ and the $8^{\text {th }}$ rib (Kelly and Micozzi 1984, 382). Unfortunately, the low preservation level of the osteological material prevented us from determining which ribs, and in what numbers, were affected by periostosis. When it comes to the individual buried in Grave G-74 at the site of Begov Most - Staničenje, aside from lesions present on the cranial and postcranial skeleton typical for scurvy, a newly formed bone on the inner side of the ribs is also visible (T. II, 3), which indicates that this child individual suffered from a chronic disease of the lower respiratory tract as well, most probably tuberculosis, although it cannot be excluded that a differential diagnosis could also be chronic pneumonia and long-lasting bronchitis, due to the weakening of the organism and reduced immune resistance cause by scurvy and vitamin C deficiency (Vulović 2020, 121). When it comes to the child individual buried in Grave G-13 at the site of Jagodin Mala - Bulevar Vojvode Mišića, a newly formed bone and destructive lytic lesions were noted on the inner surface of ribs, on both sides of the body (T. I, 4-5; T. II, 4), which also indicate that this individual suffered from a chronic disease of the lower respiratory tract, most probably tuberculosis.

As shown in the text, there is a clear difference in the manner of manifestation of the periosteal reaction on ribs. Because of all that was mentioned, it is necessary that the location and aspect of lesions be described clearly during an anthropological analysis, and, if possible, that places on which ribs these lesions occurred be noted, in order to ensure a more precise establishing of a correct diagnosis and interpretation of the results of the analysis. 

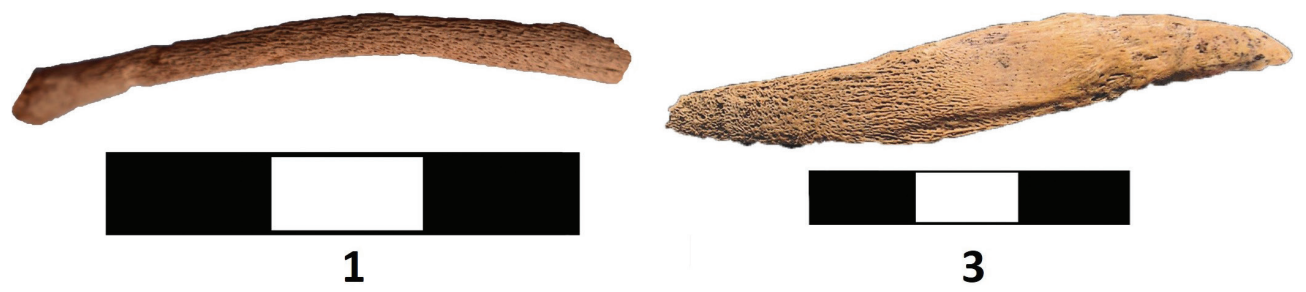

3
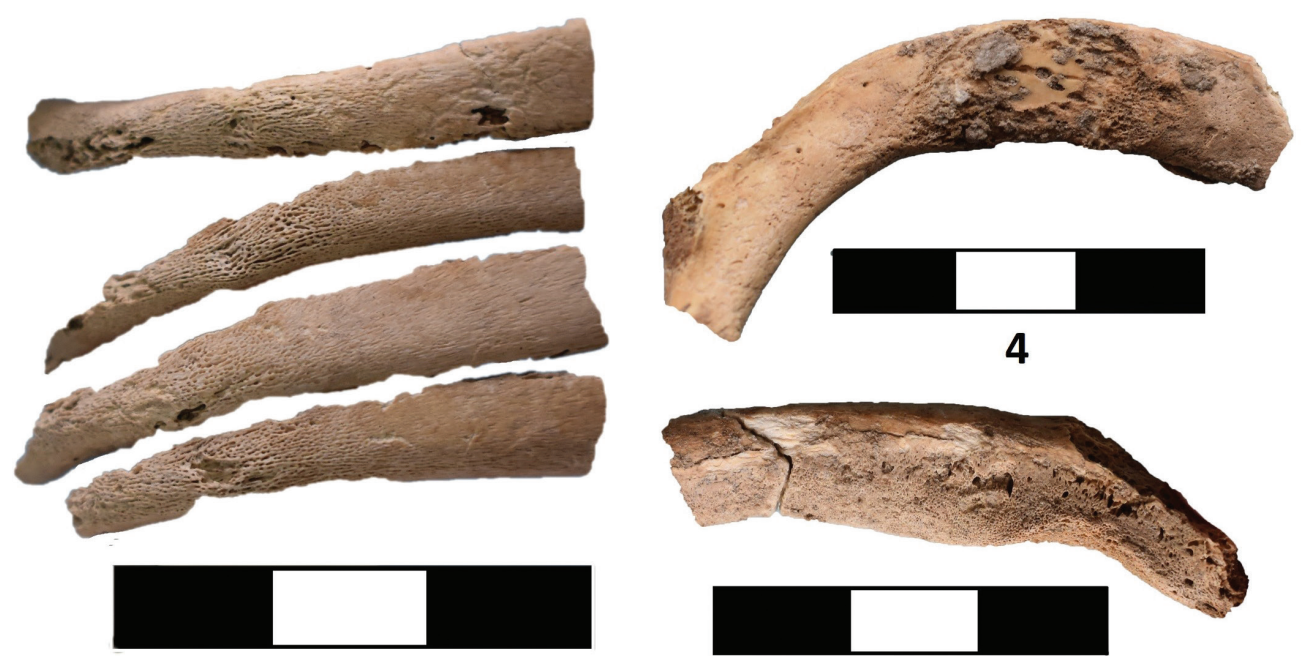

2

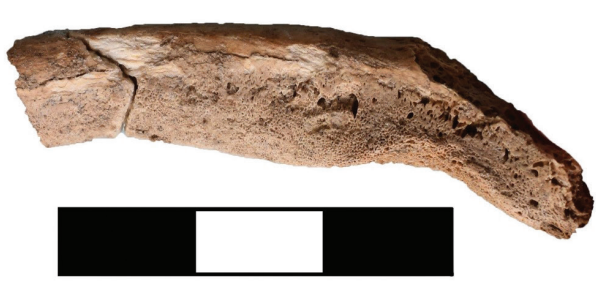

5

T. I 1. Дубље изнад куће, Нови Пазар, гроб 108/II; 2. Маџарско брдо, Рудник, гроб 6; 3. Сингидунум, гроб 1 (Miladinović-Radmilović and Vulović 2015, 193, Plate II, fig. 5); 4-5. Јагодин мала - Булевар војводе Мишића, Naissus, гроб 13 PI. I 1. Dublje Iznad Kuće, Novi Pazar, Grave 108/II; 2. Madžarsko Brdo, Rudnik, Grave 6; 3. Singidunum, Grave 1 (Miladinović-Radmilović and Vulović 2015, 193 , Plate II, fig. 5); 4-5. Jagodin Mala - Bulevar Vojvode Mišića, Naissus, Grave 13 

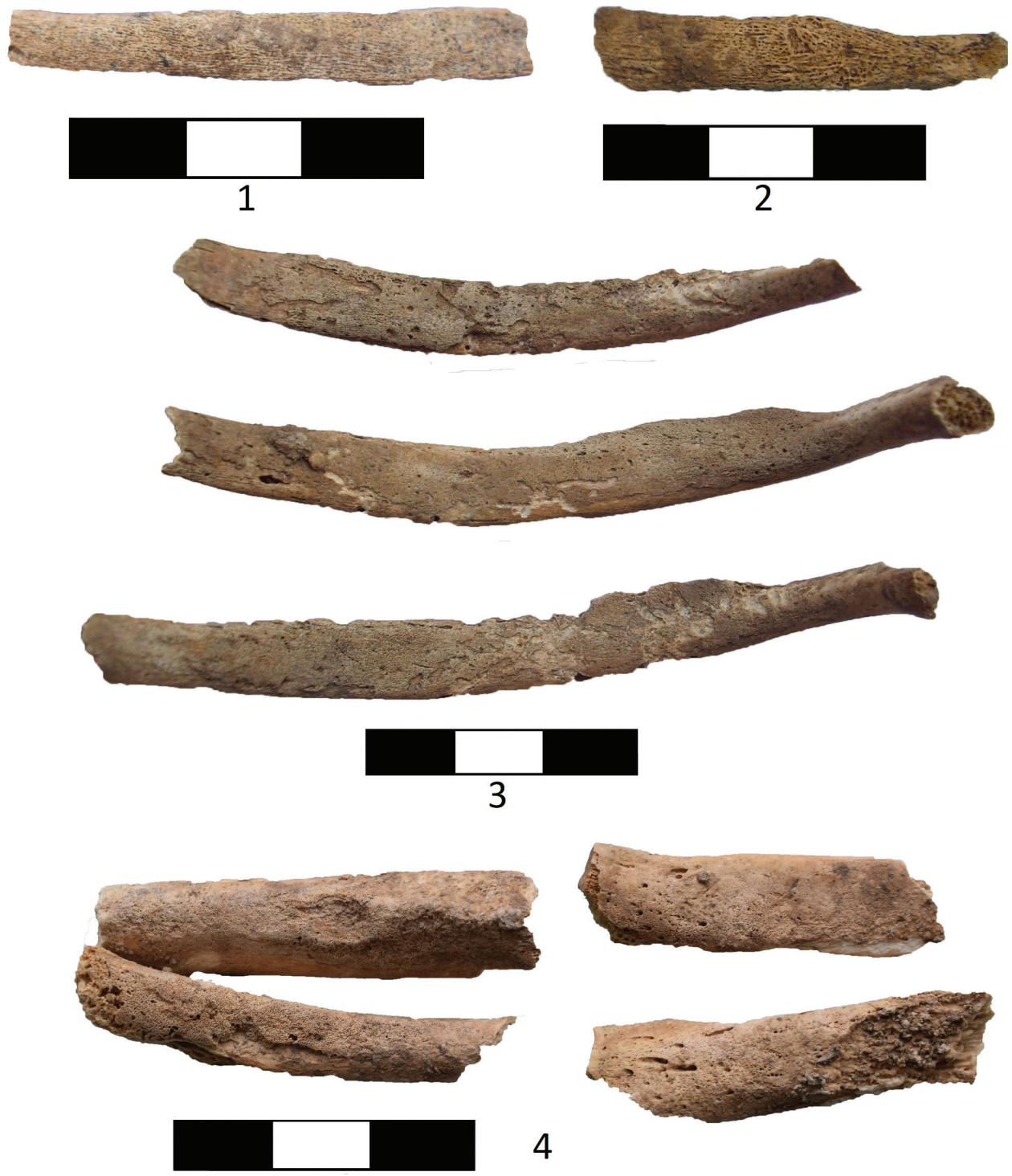

T. II 1-2. Бегов мост - Станичење, гроб 14; 3. Бегов мост - Станичење, гроб 74; 4. Јагодин мала - Булевар војводе Мишића, Naissus, гроб 13

PI. II 1-2. Begov Most - Staničenje, Grave 14; 3. Begov Most - Staničenje, Grave 74; 4. Jagodin Mala - Bulevar Vojvode Mišića, Naissus, Grave 13 